\title{
Christian Dior'un New Look Akımı Corolle Koleksiyonu İçerisindeki Bar Modelinin Göstergebilim Çözümlemesi
}

\section{A Semiotic Analysis on The Bar Model in The Christian Dior's New Look Trend Corolle Collection}

\section{Gökçe Özdemir}

Dr. Öğr. Üyesi, Gaziantep Üniversitesi, Güzel Sanatlar Fakültesi, Tekstil ve Moda Tasarımı Bölümü

email: gozdemir382@gmail.com DORCID ID: https://orcid.org/0000-0002-2608-6004

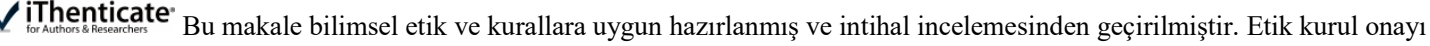 \\ gerektirmemektedir. \\ Atıf (APA 6)/To cite this article \\ Özdemir, G. (2020). Christian Dior'un New Look akımı Corolle koleksiyonu içerisindeki bar modelinin göstergebilim çözümlemesi. Atatürk \\ Üniversitesi Güzel Sanatlar Enstitüsü Dergisi, 26(45), 580-587. doi: https://doi.org/10.35247/ataunigsed.753369
}

Makale Gönderim Tarihi/Received: 15/06/2020

Makale Kabul Tarihi/Accepted: 21/09/2020

Makale Yayın Tarihi/Published: 22/10/2020

Research Article/Araştırma Makalesi

Öz

Tarih boyunca kadınlar toplumdan soyutlanarak kendi benliklerinden uzaklaştırılmaya çalısılmışlardır. Fakat bunun yanısıra sürekli kendini yenileyen moda akımları sayesinde kadınların fiziksel ve kişisel özelliklerini özgür bir biçimde yansitabilecekleri alanlar dönemin zor sartlarında bile hiz kesmeden yenilenmeye devam etmiştir. Savaş sırasındaki kısitlamalara rağmen, modadaki bu kendini yenileyen trendin harika bir örneği birçok ünlü tasarımcıya, muhteșem tasarımlar yaparak ilham vermeyi başaran Christian Dior'un yarattığ Corolle koleksiyonu olmustur. Bu çalışmada da Ronald Barthes'ın genis bir kitle tarafından kabul görmüş göstergebilim yöntemi ile Christian Dior'un New Look (Yeni görünüm) akımı "Corolle" koleksiyonundaki "Bar" modelinin, tasarım özellikleri, kullanım biçimleri ve yansitılan "anlamlama" ve "anlama" evrelerinin çözümlenmesi amaçlanmıștır. Calışmada, Barthes'nin anlamlandırma şemasından yola çıkılarak göstergeler, gösteren/gösterilen, dizim/dizge, düzanlam/yananlam karșıtlıkları ile açılanarak, mitler ile anlamlandırılma ilişkisi üzerinde durulmuş ve yorumlanmıştır. Araştırma sonucunda, anlamlandırmanın birinci düzlemi olan düzanlamda; göstergelerin tümünün göstereni ve gösterileni arasındaki ilişsi olduğu ve göstergenin gercek nesnesi ile benzestiği belirlenmiștir. Dior'un, bu modelde farklı işlevlere sahip giysi parçalarını, birbirleriyle ilişkilendirilerek dizimsel bağlantı ile anlamlı bir bütün olușturduğu görülmektedir. Yananlamda ise; dizimsel bağlantıda, parçaların birleşmesini düzenleyen kuralların, giysinin anlamını değiștirdiği görülmüștür. Ayrıca, sözcüklerin anlamlarını nesnelerin ifade etmesi ile tüm göstergelerde farklı düzeylerde anlamlandırmanın mitlerle ilişkilendirildiği gözlenmiştir.

Anahtar kelimeler: Moda Tarihi, Göstergebilim, Gösterge, Christian Dior,

\section{Abstract}

Throughout history, women have always been tried to be removed from their selves by isolating from their cultures. However, in virtue of the constantly self-renewing trends in fashion, the fields where women can freely reflect their physical and personal characteristics continued to be renewed even under challenging conditions of the period. Notwithstanding restrictions during the wartime, a great example of this self-renewing trend in fashion had been the Corolle collection created by Christian Dior, who managed to inspire many famous designers by making magnificent, excellent designs. The aim of this study is to analyze the design features, usage styles and reflected "meaning" and "understanding" phases of the "Bar" model in Christian Dior's New Look trend "Corolle" collection through the widely accepted semiotics method of Ronald Barthes. In the study, based on Barthes' distinguishing matrix, the signs are explained with the oppositions of signifier/signified, syntagm/paradigm, denotation/connotation and the correlation between myths and interpretation is emphasized and interpreted. As a result of research, the "denotation" which is in the first plane of signification, it has been determined that all of the indicators have a relationship between the signifier and the signified, and that the indicator is similar to its real object. It is understood that in this model Dior has created a meaningful whole with syntactic connection by relating clothing pieces with different functions to each other. In the connotation and in the syntagmatic relation, it has been observed that the rules regulating the combination of parts change the meaning of the clothing. Besides, It has been observed that the expression of the meanings of the words and the different levels of interpretation in all signs are associated with the myths.

Keywords: History of Fashion, Semiotics, Sign, Christian Dior.

\section{Giriş}

Toplumsal statünün, sınıfsal farklılıkların ve cinsiyet rollerinin en belirgin göstergelerinden biri olan ve kimliğin birçok farklı boyutunu doğrudan yansıtan giysilerin taşıdı̆̆ sınıfsal çelişkilere bağlı olarak başkalaşım geçirmektedir. Giyim; din, 1rk, cinsiyet, etnik köken gibi birçok kişisel özelliği yansıtan ve yansıttığı bu özelliklerle dönemsel koşullara bağlı olarak değişen bir olgudur. Bundan dolayı, tekstil ve moda geçmişten günümüze süregelen ve çeşitli dönemlerde farklılıklar gösteren birer kavramdır. Aynı zamanda da toplumun istek ve ihtiyaçları doğrultusunda değişime uğramaktadır. 1940'lı yıllara bakıldığında II. Dünya Savaşının yaşandığı yıllar olmasından dolayı giyimde değişim ve kısıtlama söz konusu olduğunu söyleyebiliriz. Bu kısıtlamaya karşın "New Look" adı verilen akım Christian Dior tarafından yaratılmıştır. Ünlü tasarımcı, 1947 yılında sergilediği ilk Haute Couture koleksiyonu "Corolle'i”" savaş zamanının kısıtlamalarına rağmen geniş ve uzun kumaşlardan hazırlamıştır. Koleksiyon, tam daire etekleri ve bel altına kadar uzatılmış 
belden aşağısı genişleyen formlu ceketleri ile savaşın kadınlar üzerindeki mütevazi ve sade tarzına başkaldırı niteliğindedir. Tasarımcı bu akımla volümlü etekler, yuvarlanan omuzlar, büstiyerler, ince belli ceketler ve uzun eteklerle feminenliği vurgulayan yeni bir kadın giyim tarzı oluşturmuştur. Öyle ki koleksiyonu gördükten sonra kayıtsız kalamayan zamanın Harper's Bazaar Editörü Carmel Snow: "Christian, bu küçük bir devrim, elbiselerin yeni bir görünüm” diyerek Dior’un yarattığı akımın adını da belirlemiş oldu. Yeni Görünüm akımı feminen duruş ve zarafete vurgu yapan özellikle de ince beli öne çıkaran, kadınların var olan güzelliklerini gözler önüne sermelerine yardımcı olan ve yaşadığı dönemin olaylarından beslenen bir akımdır. Christian Dior, bu akıma romantik bir duruş kazandırmış ve 1940'ların sonundan 1950'li yılların ortalarına kadar moda dünyasına egemen olmayı başarmıştır (Frog, 2014). Akım, savaşla birlikte gelen yoksullukla 1947 yılında ortaya çıkmış ve kendi gelişim zeminini hazırlamıştır. Kadınların fitrat olarak modaya daha meraklı olmaları da bu akımı kolayca benimsemelerine yardımcı olmuştur. Bu da kişisel görünümlerinde işlerine yarayacak kolay yöntem bulmalarına sebep olmuştur. Bu yeni akım savaş alanında psikolojik olarak yıpratılarak manipüle edilmeye çalışılan kadınların giyimini bir başkaldırı niteliğinde değiştirip bir anda renkli bir hale getirmiştir. Bu süreçte yaşanan kemer sıkma politikaları kadınların New Look ile beraber giyimde bir devrim yaşamasını sağlamıştır. Savaş dönemi kısıtlamalarında pili sayılarının kontrolü, eteklerin kalem etek formunda diz üstü dikilmesi, aksesuarların az kullanımı sonunda savaşın bitmesiyle çıkan bu yeni görünüm ile tam daire etekler, kumaştan aksesuardan kaçılmamış tasarımlar çok ilgi görmüştür. Koleksiyonun ilk gösterimini "Corolle” yaptığından, bu akım dünya çapında yadırganmadan emsalsiz bir şekilde dikkat çekerek ün kazanmıştır ("Christian”, 2018).

12 Şubat 1947 yılında Christian Dior'un yarattı̆̆ de kadınların aradıklarını bulmaları ve bu kıyafetlerle çekici hissetmeleri sağlanmıştır. Bu başkaldırı akımı ile birlikte düşüşte olan modanın nasıl toplandığı ve savaştan çıkıp nasıl silkelendiğini, özüne döndüğü açıkça gözlemlenebilmektedir. Prenses Margareth’in 21. yaş gününde giydiği New Look koleksiyonun önemli parçası dikkatleri bu yeni akıma çekmiştir. Artık kadınlar bel hatlarını ortaya çıkaran elbiseler, kabarık tam daire havalı etekler giymeye başlamışlardır. Şapka ve ayakkabı boyları yükselerek apartman topuk ayakkabılar tahta ya da mantardan yapılmaya başlanmıştır. Korse ve jartiyer kullanımı New Look akımı ile birlikte devam ederek şapka ve eldiven kullanımı her zamanki ihtişamı ile bayanların kıyafetlerini taçlandırmıştır (Girişmen, 2015). Bu akımın en genel özellikleri; omuz vatkalarının yerini, yuvarlak omuz hatlarına bırakması, uzun kabarık elbiseler ile kalem eteklerin birlikte kullanılmasıdır diyebiliriz. Ayrıca, eteklerin bel formu vücuttaki yuvarlak hatları öne çıkaracak şekilde tasarlanmıştır. Yelpaze kırmalı pililerde ipek kumaşla birlikte bu etek formunu sağlamak için kullanılmıştır. Gece ve gündüz elbiselerinin boyu kısaltılarak, diz altı - bilek üzeri gibi bir aralık tercih edilmiştir. Ceketler bel hattına kadar uzatılmış genelde bele kadar oturan belden aşağısı genişleyen ceket formları kullanılmıştır. Ayrıca belden kesikli ve bel kısmında kemer kullanılan ceketlerde ön plana çıkmaya başlamıştır. Göğüs kısmı vücuda oturur, tüm bu modellerde ortak özellik olarak bu çok belirgindir (Frog, 2014).

O dönem bu akımdan etkilenen birçok ünlü modacı olmuştur. Bunlardan bazıları; Christobal Balenciaga, Pıerre Balmaın ve Channel'dir. Günümüzde ise John Galliano, Betsey Johnson, Marc Jacops, Vivienne Westwood gibi ünlü isimler bu akımdan etkilenen başlıca tasarımcılardan olmuşlardır. Özellikle Dior, Hause'un baş tasarımcısı olan John Galliano neredeyse her yıl, New Look akımını günümüze uyarlayıp moda severlerle buluşturmaktadır (“Christian", 2018). Bu akımı bir bütün olarak değerlendirdiğimizde, 1940’lı yıllardan günümüze kadar devan eden bir süreci kapsaması ve ortaya çıktığı dönemde moda da toplumsal bir başkaldırıyı temsil etmesi nedeniyle, tasarımların verdikleri mesajların ortaya çıkarılması ve tasarımların detaylı çözümlemesinin önemli hale geldiğini söyleyebiliriz.

Göstergebilimsel analiz yöntemi, amaç anlamlı bir bütünü çözümlemeyi hedefleyen, bu işlevini de her türlü iletişim etkinliklerinde yer alan gösterge dizgelerinin kullanılarak yapıldığı bir disiplin olarak karşımıza çıkmaktadır. Göstergebilimsel araştırmanın amacı; her türlü yapısal etkinliğin, gözlemlenen konuların bir taslağını yaratmaya yönelik tasarısına uygun olarak, dil dışındaki anlamlama dizgelerinin işleyişini belirleyip ortaya koymaktır (Barthles, 1967'den aktaran Kırkıncıoğlu, 2015). Göstergelerin anlamları üzerine antik çağdan beri çeşitli görüşler ileri sürülmüştür. İnsan düşüncesi ve bildirişiminin göstergeler aracılığıyla işlediği fikri, çeşitli filozoflar tarafından çok eski çağlarda dile getirilmiştir (Rifat, 1992). Amerikalı filozof Charles Sanders Peirce (1839-1914) ve İsviçreli dilbilimci Ferdinand de Saussure (1857-1913), eşzamanlı olarak 20. yy’ın başlarında, çağdaş göstergebilimin temellerini atmışlardır (Vardar, 2001). Günümüzde bireylerin, önceki dönemlerle kıyaslandığında birçok iletişim teknikleri kullanılarak çok yoğun bir mesaj ve algı yönetimi yağmuruna tutulduğu görülmektedir (Berger, 2008). Bu yoğun mesaj ortamında her bir imgenin belleğimizde oluşturduğu çağrışımların çözümlenebilmesine, birçok disiplinle de ilişkisi bulunan göstergebilimin sahip olduğu yöntemler yardımcı olmaktadır. Bir giysiyi anlamlandırabilmek, onu oluşturan değerleri görmek, kendine özgü yapısını kavramak, onunla bir iletişime girebilmek ve göstergeleri okuyabilmek, göstergebilim ile geliştirilebilecek bir olgudur (Batu, 2011).

Göstergeler iletişim kurmak için insanlar tarafından üretilmişlerdir. Bir düşünce, görüş, yeni çıkan bir ürünün varlığı gösterge yoluyla bir başkasına aktarılır. Düşünmek, göstergeleri kullanmak ve işletmek demektir. 
Düşünmenin var olması, paylaşılması ve gelişmesi bütünüyle göstergelere bağlıdır. Bireysel isteklerin aynı gösterge türüyle anlatılması zor olabilir. Bu nedenle insanlar görüntüsel, sözel olan veya sözel olmayan her türlü yapılar gibi farklı türden göstergeler kullanabilmektedir. Hatta toplumsal olarak kullanılan her şey göstergedir ve bir iletişim değeri vardır (Günay, 2008).

Çağdaş göstergebilimin önemli bir ismi olan Roland Barthes, geliştirmiş olduğu özgün yaklaşımla daha çok popüler kültür çözümlemeleri üzerinde çalışmıştır. Barthes'ın geliştirdiği yapısal çözümleme yöntemi, bildirişim amacı içermemekle birlikte anlam taşıyan çeşitli olguları (giyim, mobilya vb.) ele almaktadır. Barthes, bütün bunları anlamlama (signification) kavramı aracılığıyla göstergebilime bağlar, göstergelerle ikincil gösterilenler ya da yan anlam gösterilenleri arasındaki bağıntılar üzerinde durur (Vardar, 2001). Günlük iletişimde kullanılan, kültür ya da kültürün bir parçası olarak nitelenen her şey, gösterge diye adlandırılabilecek uzlaşımsal değerleri toplumun benimsediği biçimde kullanılmayı gerektirir. Her türlü kültür olgusu anlamlı bir yapıdır ve bir toplum için çok şeyi belirtebilir. Ancak her türlü göstergeyi kullanmak için kendi kullanım yerlerini bilmek gerekir. Bu da toplumsal yaşamla ilintili bir durumdur. Sonuç olarak günlük yaşamdaki iletişim, toplumsal olarak yaşamanın gereği, dilsel ve dil dışı göstergeleri bir arada kullanmakla mümkün olabilir (Yıldız ve Başak, 2019). Barthes, "göstergelerin ilk işlevi anlam iletmek gerekliliğinden yola çıkarak; göstergenin ilk anda işaret ettiği şeyin "düzanlam", gösterge ile kültürel çağrışımları arasındaki farklılıkların ise "yan anlam" düzlemlerinde araştırılması gerekliliğini savunmuştur (Parsa, 2004). Bir bildirinin anlamlandırılması sürecinde, geliştirdiği kuram ile okuyucuya yardımcı olmayı amaçlayan göstergebilim, bu nedenle değişik okuma düzeyleri önermiş ve anlamını ortaya koymak için de farklı yöntemler geliştirmiştir. Diğer yandan, anlam yaratan her gösterge grubu aynı özellikte olmaması ve göstergenin kendisinden ya da kodundan kaynaklanan özellikleri olması nedeniyle, genel göstergebilimin alt evrelerini oluşturmaktadır. Son yıllardaki çalışmalarla giysi göstergebilimi de bu alt bilimlerdeki gelişmelerde yerini almaktadır. Çünkü göstergebilim ile giysilerin taşıdığı anlamların, nasıl açıklanması gerektiği bir bağlam kuramı çerçevesinde açıklanabilmektedir (Barnard, 2002). Giyim-kuşam göstergebilimsel yaklaşımla ele alındığında, görsel gösterge olarak giysinin dili, giysinin kodu, giysinin anlamı, giysinin sembolik değeri, giysilerin dizimi yani giysiyle sağlanan sözsüz iletişim karşımıza çıkmaktadır (Koca ve Kırkıncıoğlu, 2016). Çünkü bir giysi kendisini oluşturan unsurların oluşturduğu bir bütündür ve farklı değişkenlere bağlı olarak farklı anlamlar kazanabilmektedir. Giysi parçalarının bir araya gelerek oluşturduğu giyim kuşam biçimi, giysiyi taşıyanın ve onu yorumlayanların, kimliğini, düşüncelerini, ruhsal durumunu, görüş ya da inancını yansıtmakta aktif rol oynayan giysi kodları; duruma, yere, topluluğa göre farklı değerlendirilmektedir. Toplumsal olarak kullanılan sözel olan veya sözel olmayan her şeyin iletişim değeri sağlayan bir gösterge biçimi olduğunu ve aynı mesajı iletmede herkesin ayrı göstergeler kullanabileceğini vurgulamaktadır. Parsa, görüntülerle temsil ettikleri nesneler arasında çoğunlukla benzerlik olduğuna ve beraberinde çağrıştırdığı yeni bilgiler ve anlamlar da içerdiğine dikkat çekmektedir. Davis (1997), bu durumu "cenaze kıyafetinin bir parçası olan siyah tül ile bir tuvalette kullanılan siyah tül, aynı malzeme oldukları halde, farklı bağlamlarda tümüyle farklı anlamlar taşırlar" örneğiyle açıklamaktadır. Geçmişten günümüze yaygın bir iletişim aracı olan giysi dili, uyaranları anlamlandırmak için kategoriler içine yerleştirilerek düzenlenebilir. Giysinin kesimi, biçimi, seçilen renk, desen ve doku, aksesuar ve takılar, malzeme ve menşei, giysi dikim teknikleri, süslemeler, ortak anlamlara ulaşmış sembollerin taşınması gibi kavramlar, giysi göstergebilimini oluşturmaktadır. Bu kavramların pek çoğu, tüketici tarafından, tercih edilip taşınır. Bireyin üzerinde taşıdığ düzeyini, sosyal statüsünü, meslek grubunu açık bir şekilde yansıtmaktadır. Herkesin ne anlama geldiğini bildiği göstergeler zamanla ortak bir kod haline gelerek giyim kodlarını oluşturur. Giyim kodları incelendiğinde; toplumsal veya bireysel pek çok bilgiye ulaşmak mümkündür. Koç (2009), giysi kodları ile bir kișinin içinde bulunduğu ruh hali, statüsü, kültür düzeyi, davranış kalıpları hakkında bilgi sahibi olmanın mümkün olacağını ifade etmektedir. Aynı şekilde bir toplumun gelenek ve görenekleri, estetiksel, sanatsal özellikleri; değerler sistemi, ekonomik durumu, geçim kaynakları, diş etkenlerden etkilenme durumu gibi pek çok konuda fikir sahibi olunabileceği gözlemlenmiştir. Giyim kodu, iletişimde kullanılan alışılmış gösterge kodlarından çok, estetik koda yakındir.

Göstergebilim sistemini giysilere uyarladı̆̆ımızda, "gösteren” ve "gösterilen” arasındaki ilişki, giysinin formu, rengi, motifi veya birtakım başka öğeler ile ifade edilen, çağrıştırılan ya da ima edilen sembolik evren arasında kurulan sistematik bağ incelenmektedir. İşte bu çağrıştırılan ya da "gönderme yapılan” alanın nasıl yorumlandı̆̆ı, bir toplumdan diğerine, bölgeden bölgeye, hatta ilden ile farklılık göstermektedir. Batı toplumunun giyim kodunda gösteren/ gösterilen ilişkisinin topluluk veya toplumlara göre değişiklik gösterdiği şöyle ifade edilmiştir: "Bir tarz, bir görünüm ya da belli bir moda akımı oluşturan gösteren, maddi anlamda herkes için aynı kabul edilse de, gösterilen (belirtilen, anlaşılan, çağrıştırılan, ima edilen ya da ifade edilen), en azından başlangıçta, kitlelere, seyircilere ve toplumsal gruplara göre çarpıcı farklılıklar içerir: Muhafazakar olan ile deneyciliğe yatkın olan, modayla çok ilgili olan ile modaya kayıtsız kalan, modanın yaratıcıları ve modacılar zümresi ile tüketiciler, hatta nispeten sofistike tüketiciler arasında bir farklılık söz konusudur (Davis, 1997). 
Giyimde göstergeler, iletişim levhalarında olduğu gibi üzerinde kesin olarak anlaşılmış kodlarla değil, tarihsel ilişkilendirmeler ve birtakım çağrışımlarla anlam oluştururlar. Anlamlar, göstergeler arasındaki farkın ya da ilişkinin bir ürünüdür. Anlamlandırmanın birinci düzeyi, Saussure’ün üzerinde çalıştığı düzeydir. Bu düzey, göstergenin göstereni ve gösterileni arasındaki ilişkiyi ve göstergenin dişsal gerçeklikteki göndergesiyle ilişkisini betimler. Barthes bu düzeyi düz anlam olarak adlandırır. Düz anlam, göstergenin ortak duyusal, aşikâr anlamına gönderme yapar (Fiske, 2003). Anlamlandırmanın önemli ikinci düzeyi de yan anlamdır. Alıcıların hepsi tarafından aynı biçimde algılanmayan ya da algılanamayan ikincil kavramlara, imgelere, öznel izlenimlere ilişkin olan duygusal, coşkusal ikincil anlamlara yan anlam denir (Özmutlu, 2009).

Giysilerin tasarım malzeme ve biçimsel özelliklerinin yanında anlamsal yapının da belgelenmesi gerekmektedir. Biçimsel açıdan belgeleme konusunda yapılmış çalışmalar olmasına rağmen ünlü tasarımcı Christian Dior'un bir devrim yaptığ 1 New Look akımı "Corolle" koleksiyonuna yönelik çalışmalarının yeterli olmadı̆̆ düşünülmektedir. Bu sebeple göstergebilimsel çözümleme yöntemleri ile giysilerinin taşıdığı anlamların okunur hale getirilmesi sağlanabilir. Rengi, dokusu, malzemesi, kullanım biçimi ve anlamı ile bir yaşam biçimini yansıtan giysi fotoğraflarının aktardığı görsel iletilerin anlamlandırılmasının, Barthes'ın deyimiyle giysinin yazıya dönüştürülmesiyle olabileceği çalışmanın çıkış noktasını oluşturmuştur. Göstergebilimin; anlam evrenini çözümleme, anlam oluşumu, anlam yaratma, anlamlandırma gibi soyut durumun dizgeleştirilmesi, açığa çıkarılması gibi konuları kapsama düşüncesinden hareketle bu çalışmada, Christian Dior'un New Look akımı (1947) "Corolle" koleksiyonu içerisindeki "Bar" modeli tasarımının Roland Barthes’ın uygulamış olduğu (gösterge, gösteren, gösterilen) göstergebilimsel okuma ile çözümlenmesi amaçlanmıştır.

\section{Yöntem}

Bu çalışmada, ünlü tasarımcı Christian Dior'un yaratmış olduğu New Look (Yeni Görünüm) akımı "Corolle" koleksiyonundaki "Bar" modelinin ve kullanılan aksesuarların; kullanım biçimi, amacı, tasarım özellikleri ve yansitılan "anlamlama" ve "anlama" evrelerinin göstergebilimsel okuma ile çözümlenmesi amaçlanmıştır. Bu bağlamda çalışma, nitel bir araştırmadır. Nitel araştırmalar, anlam ve anlama üzerine odaklanan, araştırma verisindeki nedenleri ve etkileri tümevarımsal bir süreç içerisinde ele alan bir araştırma türüdür (Merriam, 2013). Çalışmada, Barthes'in anlamlandırma şemasından yola çıkılarak göstergeler, gösteren/gösterilen dizim/dizge, düzanlam/yananlam karşıtlıkları ile açıklanmış, söylem yani mitler ile anlamlandırılma ilişkisi üzerinde durulmuş ve yorumlanmaya çalışılmıştır.

Barthes anlamlandırmanın iki düzlemini ikili karşılıklar biçiminde ortaya koymaktadır. Aynı zamanda, anlamların kültürel pratikler içinde toplumsal karakterlerin konum ve tavırlarına nasıl etki ettiğini inceleyerek, işlevselliklerini dilin içinde anlam, kodlar, düzanlamlar, yananlamlar ve mitler adını verdiği düzeylerde yapılandırmaktadır. Anlamlandırmanın ilk düzeyi olan düz anlam, göstergenin işaret ettiği şeyi, ikinci düzeyi olan yan anlam ise göstergenin kullanıcıların kültürel değerleriyle buluştuğunda oluşan etkileşimi betimlediğini belirtir ve ikincil gösterilenler ya da yananlam gösterilenleri arasındaki bağıntılar üzerinde durur (Fiske, 2003). Roland Barthes göstergebilimin temel konusunun anlam olduğunu belirtir. Ona göre tüm dizgeler birer anlamlama dizgesi oluştururlar. Dil/söz, gösteren/gösterilen, dizim/dizge, düzanlam/ yananlam karşıtlıklarını göstergebilimin başlıca çözümleme araçları olarak benimsemiştir (Barthes, 2012). Bu araştırmanın çalışma evrenini; 1947 Christian Dior'un New Look akımı "Corolle" koleksiyonu içerisindeki "Bar" modeli oluşturmaktadır.

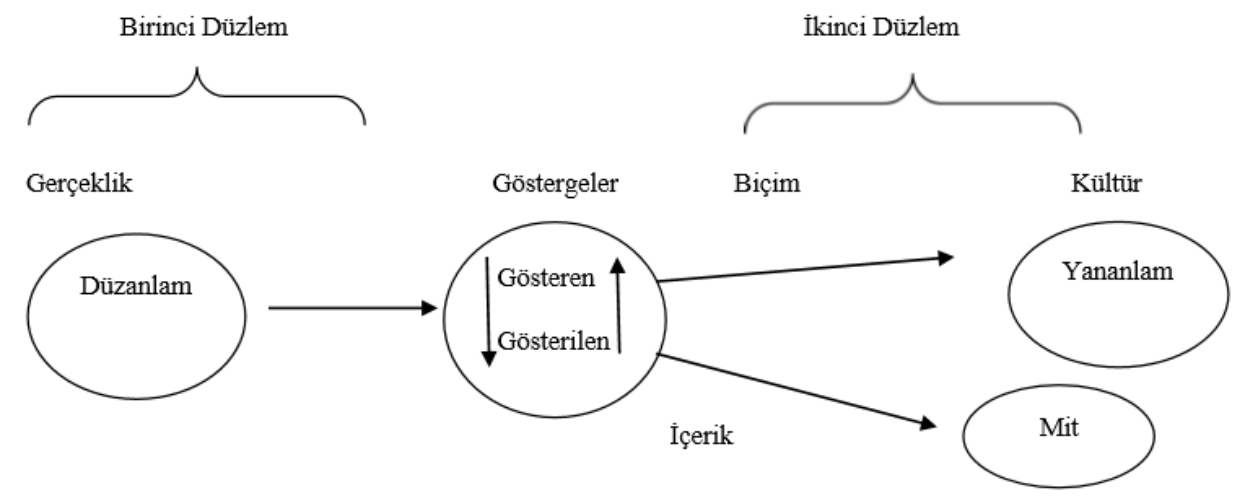

Şekil 1. Roland Barthes’nin anlamlandırma şeması (Fiske, 2003)

\section{Bulgular}

Moda, toplumların geleneklerin, olayların bir büyülü aynasıdır. Savaşlar, barışlar, buluşlar, sanat olayları modayı her açıdan etkilemektedir ("Moda", 2016). Giyim bir toplumun yaşam tarzını, gelenek ve göreneklerini, yaşanılan 
çağın sosyal, ekonomik ve kültürel yapısını en iyi yansıtan gösterge olarak ifade edilmektedir (Köse, 2007). Araştırmada ünlü tasarımcı Christian Dior'un yaratmış olduğu New Look akımı Corolle koleksiyonu içerisindeki "bar" modeli göstergebilimsel olarak yorumlanmaya çalışılmıştır. Alan taraması sonucu elde edilen bilgiler neticesinde tasarımcı, savaş dönemindeki kısıtlamalara tepki niteliğinde bir koleksiyon geliştirip, giyimde tek tip ve erkeksi görünümün aksine kadınların ince belini ortaya çıkaran ceketler ve kalça hattını kabarık gösteren etekler tasarlayarak kadınsılığı ve unutulmuş kadın bedenini gün yüzüne çıkarmayı amaçlamıştır. Christian Dior'un yaratmış olduğu New Look akımı Corolle koleksiyonu içerisindeki "bar” modelinin gösterge, gösteren ve gösterilen bağlamında çözümlemesi Tablo 1'de yer almaktadır.

Tablo 1

Christian Dior 1947 New Look (Yeni Görünüm) Akımı “Corolle” Koleksiyonu "Bar” Modelinin Görüntüsel Gösterge Olarak Bilimsel Yöntem ile Çözümlenmesi

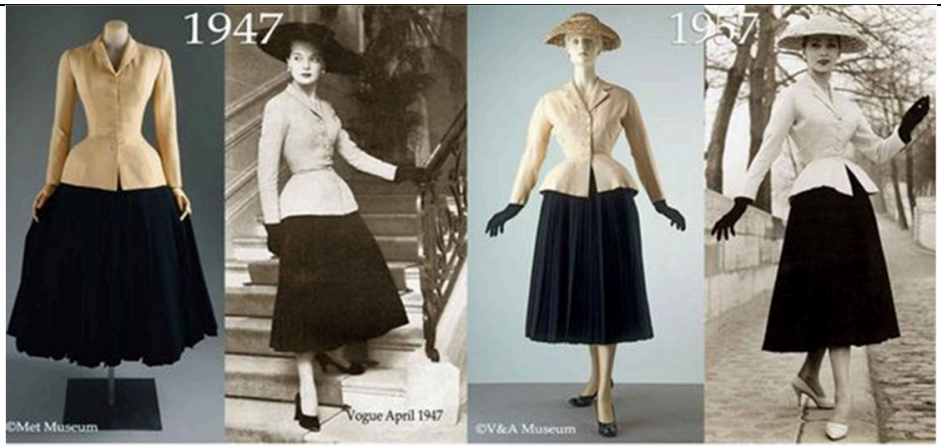

Christian Dior - The Original "Bar Suit" (left) and the 1957 version (right)

\begin{tabular}{|c|c|c|}
\hline Gösterge & Gösteren & Gösterilen \\
\hline Kadın & Bar suit & Etek-ceket takım \\
\hline Nesne/ Obje & Etek & $\begin{array}{l}\text { Bar modeli olarak tasarlanmış, kalın düz pili, siyah yün kumaş, diz altına gelen (midi } \\
\text { boy ) kabarık stil }\end{array}$ \\
\hline Nesne/ Obje & Ceket & $\begin{array}{l}\text { Kum saati görünüm, bele oturan, belden aşağısı bombeli inen, kırık beyaz, Çin ipeğinden } \\
\text { yapılmış şantuk kumaşından üretilmiş yumuşak hatlı omuzlara sahip, gögüs bölgesini } \\
\text { vurgulayan ve kalça bölgesi at kılı dolguya yaklaşık } 48 \mathrm{~cm} \text { uzatılmış bar modeli olarak } \\
\text { tasarlanmış ceket. }\end{array}$ \\
\hline Nesne/ Obje & Ayakkab1 & Sivri burunlu ve k1sa topuklu ayakkabı. \\
\hline Nesne/ Obje & Eldiven & Uzun, siyah- süet \\
\hline Nesne/ Obje & Hasır şapka & Giysi tamamlayıcısı, aksesuar. \\
\hline
\end{tabular}

Tablo 1'de, göstergelerin, gösteren ve gösterilen ilişkisi incelenmiştir. Tarihsel bakış açısıyla giysiler; renk, kumaş, biçim, detay, baskı, siluet ve kesim gibi çeşitli unsurları içerisinde barındırarak kendi türlerinden farklılık taşımaktadırlar. Tablo 1'deki göstergeler incelendiğinde, bar modelinin etek ve ceket takımı olarak iki parçadan oluştuğu görülmektedir. Üst giysi olan ceket; erkek yaka, bedene düz takılan, iki parçalı ceket kol, kolda iki adet düğme, ön bedende kol oyuntusunda başlayıp cep ağzında biten kup, arka bedende kol oyuntusunda başlayıp belde biten kup, bedeni saran belden aşağısı daire sistemli, kapaklı çift fileto cepli, tek sıra kapanma payına sahip, kapanma payında 5 adet ilik düğmesi olan ve astarlı bir yapıdadır. Etek ise siyah yün kumaş, midi boy, pilili ve tam daire modelindedir. Giysiyi tamamlayan aksesuar olarak; sivri burunlu kısa topuklu ayakkabı, siyah süet eldiven ve hasır şapka kullanmıştır.

Tablo 2

Dizge ve Dizim Olarak Christian Dior'un Bar Modeli Giysi Analizi

Bar model, etek ve ceket olmak üzere iki parçadan oluşmaktadır.
Model gündüz ve gece saatlerinde dişarı çıarken giyilebilecek bir tasarım özelliği taşımaktadır.
Hasır şapka, siyah deri eldiven ve sivri burun ayakkabı ile kombin tamamlanmıştır.


Tablo 2'deki gösterge incelendiğinde, dizge ve dizimler açısından parçalar arasında uyum olduğu görülmektedir. Bar modeli, dizge-dizimsel olarak üst ve alt giysi olacak şekilde iki parça şeklinde dizilmiştir. Üst ve alt parça, gerek renk kombinasyonu, gerekse etekteki daire kesim formunun ceketin belden aşağı bölümünde kendini tekrar etmesi açısından birbiri ile ilişkilendirilmiştir. Ayrıca modelin gündüz ve gece saatlerine giyilebilir bir özellikte olması fonksiyonelliğini arttırarak, bu tasarım bağlamında zaman kavramı önemsiz hale gelmiştir. Göstergedeki bu anlamlı bütünlük de "dizimsel” bir bağlantının varlığını göstermektedir.

Tablo 3

Düzanlam/Yananlam Düzleminde Göstergelerin Anlamlandırılması

\begin{tabular}{|c|c|c|c|}
\hline Görsel & Gösterge & Düz anlam & Yan anlam \\
\hline & $\begin{array}{l}\text { Bar modeli: Etek ceket takım } \\
\text { Hasır şapka } \\
\text { Eldiven } \\
\text { Ayakkabı }\end{array}$ & $\begin{array}{l}\text { Siyah, yün, midi boy geniş } \\
\text { pilili, çan etek. } \\
\text { Belden oturtmalı erkek yaka, } \\
\text { belden aşağısı volanlı inen } \\
\text { ceket. } \\
\text { Hasır şapka } \\
\text { Siyah süet eldiven } \\
\text { Sivri burun kısa topuklu } \\
\text { ayakkabı }\end{array}$ & $\begin{array}{l}\text { Kum saati görünüm, ince beli, } \\
\text { feminenliği, estetik, güzel } \\
\text { görünmeyi sembolize eder. } \\
\text { Siyah süet eldiven, zerafet, } \\
\text { elegant ve lüks görünümü } \\
\text { çağrıştırmaktadır. } \\
\text { Hasır şapka romantik bir } \\
\text { görünümü çağrıştırmaktadır. } \\
\text { Sivri burun ayakkabı kadınsılığı } \\
\text { marjinalliği ve şılığı, modern } \\
\text { görünümü, çağrıştırmaktadır. }\end{array}$ \\
\hline
\end{tabular}

Tablo 3'te, göstergelerin iletişimsel olarak taşıdığı anlamların düz anlam ve yan anlam olarak sınıflandırıldığı görülmektedir. Anlamlandırmanın birinci düzlemi olan düz anlamda; göstergenin ilk anlamının dile getirildiği ve gösterilenin nesnel olarak; olduğu gibi ve yansız kavranması amaçlanarak, dış ceket ve altına giyilen etek olmak üzere, iki parça giysiden oluştuğu görülmektedir. Kırık beyaz renkli Çin ipeğinden yapılmış şantuk ceket yumuşak hatlı omuzlara sahip, gögüs bölgesini vurgulayan ve kalça bölgesi at kılı dolguyla uzatılan bir görselliğe sahiptir. Yaklaşık 48 santimetrelik bel genişliğiyle hazırlanan bu ceket, kabarık parçalarıyla kalçadan baldırın ortasına inerek, hafif pilili siyah yün etekle kombin edilmiş ve bu sayede güzel bir zıtlık oluşturulmuştur. Kıyafeti tamamlamak için, sivri burunlu, siyah, süet ve kısa topuklu ayakkabı kullanılmıştır. Aksesuar olarak ise siyah eldiven ve hasır şapka kullanılarak bütünlük sağlanmıştır. Anlamlandırmanın ikinci düzeyi olan yan anlamda (çağrışım) alıcıların hepsi tarafından aynı biçimde algılanmayan ya da algılanamayan ikincil kavramlara, imgelere, öznel izlenimlerle yapılan bu betimlemede ise; görselde bulunan modelin duruş gücü, üzerindeki kıyafetler, aksesuarlar; lüks tüketimi, zenginliği, zarafeti, duygusallığı, moderniteyi, saflık ve romantikliği çağrıştırmaktadır. Yuvarlak hatlı daire, elips ya da oval gibi şekiller, insanları birleştirici yapısıyla, birlik ve dostluk mesajlarını verirken bu yapılardaki kıvrımlar ve sivri burun ayakkabıların cazibeli duruşu kadınsılığa dikkat çekmektedir. Siyah genellikle gücün ve otoritenin simgesi olarak kullanılmıştır. Bunlarla birlikte siyah, resmi, ciddi, sert, keskin ve asi bir tavır da ortaya koymaktadır. Aynı zamanda kadının kadınsı hatlarını gösteren; inceliğini, asaletini ve zarafetini tamamlayıcı unsur olarak da karşımıza çıkmaktadır. Mitlerin bir şey üzerinde düşünme, onu kavramlaştırma ya da anlamanın kültürel yolu olduğunu belirtmekte ve hayatın "mit'leri olarak adlandırdığı toplumsal davranışları, kalıpları, nesneleri de eleştirirken göstergebilimsel bakış açılarından büyük ölçüde yararlanıldığını belirtmiştir. Bu nedenle, kesimi, rengi, kullanım şekli ve süslemesi gibi tasarım detaylarına gizlenen anlamlar ve yansıttığı mesajlarla, iletişim dili olmuş giysilerin, anlam ve oluşturdukları alg1 açısından incelenmesi kültürel birikimin korunması açısından önem kazanmaktadır. Model cezbedici, heyecan verici ve kadınsı bir imajı yansıtmaktadır. Bu göstergelerin oluşturduğu anlamın bütünlüğüne göre bu parçada sunulan mit, daha fazla kadınsı daha fazla zarafet daha fazla feminen bir kadın mitidir. Koca ve Kırkıncıoğlu (2016), da geçmişten bugüne bir iletişim aracı olan giysi dilinin, giysinin kesimi, biçimi, seçilen rengi, desen ve dokusu, aksesuar ve takıları gibi uyaranları anlamlandırmak için önemli olduğuna vurgu yapmışlardır.

\section{Sonuç}

$\mathrm{Bu}$ araştırma neticesinde elde ettiğimiz sonuçlara göre, II. dünya savaşı sonrası kadınlarda oluşan özgüvensizliğin, ötekileştirmenin, yalnızlaştırılmanın etkisi Christian Dior'un bir devrim niteliği taşıyan Corolle koleksiyonuyla bambaşka bir boyut kazanmıştır. Toplum tarafından yadırganan kadın profili büyük bir özüne dönüş gerçekleştirerek ve kadınların kendi vücut hatlarının farkına varmaları sağlanarak adı gibi "New look" yani yeni bir görünüme bürünmeleri hayata bakış açılarını da etkilemiştir. Bu akım bir nevi bir başkaldırı niteliği taşımaktadır ve günümüzde hala bazı ünlü tasarımcılar tarafından kullanılmaktadır.

Araştırma kapsamında, Christian Dior’un “Bar” modeli Barthes’ın göstergebilimsel yöntemiyle çözümlenmiştir. Araştırmaya dâhil edilen modelin resimleri göstergebilimsel açıdan çözümlenirken hem teknik özelliklerine hem de sözel ya da görsel bütün göstergelerin ortaya koymaya çalıştığı kültürel yan anlamlara odaklanılmıştır. Bu 
bağlamda çalışmanın kapsamına dâhil edilen modelin incelenmesi neticesinde önemli bazı sonuçlar belirlenmiştir. Bunlar;

1. Christian Dior’un “Bar” modelinin görüntüsel gösterge olarak; güçlü, modern, şık giyinen, feminen bir görünüm yaratan kadınsı bir imaj oluşturduğu ve göstergeler arasında bir bütünlük sağlandığı sonucuna ulaşılmıştır. Ayrıca Bar modelinin etek ve ceket olarak temelde iki parçadan oluştuğu ve kullanılan aksesuarlar ile dönemin modasına vurgu yapıldığı bulgulanmıştır. Bu sonucu destekler nitelikte, Koç ve Koca (2015), giysilerin toplumsal yapıdan etkilenerek, kişisel bir dışa vurum aracı olduğunu belirtmişlerdir.

2. Dizimsel açıdan Bar modelinin üsten, alta doğru bir dış giyim olarak dizildiği sonucuna ulaşılmıştır. Ayrıca modelde kullanılan kumaş renkleri ve model kesimlerindeki genişlik ve darlıkların, göstergelerin birbirleri ile olan ilişkisini ve dizimsel bağlantının var olduğunu göstermektedir.

3. İletişimsel açıdan Bar modelinin, o dönem yaşanan psikolojik buhrandan kurtulma isteğini taşıyan bir mesaj içerdiği sonucuna ulaşılmıştır. İletişimsel açıdan görsel incelendiğinde, tasarımda, özgür ve yaratıcı ruhları ön plana çıkarmaya çalışan, yeniliklere açık modernite canlısı kadınların seslerinin topluma duyurulmasının önemsendiği görülmektedir.

Genel olarak, kullanılan görseldeki kadın figürünün kendinden emin duruşu, modern görüntüsü ve yaşanan çağa hitap ederek oluşturulmuş estetiksel yapıya sahip olması, Bar modelinin ana öğretisi olan "daha fazla zerafet, daha fazla kadınsılık, daha fazla feminen duruş" söyleminin amacına ulaştığının bir göstergesidir. Özellikle o dönemden, günümüze kadar uzanan süreçte Christian Dior'a ilham olan bu öğretinin günümüzde hala kullanılıyor olması elde edilmek istenilen başarının da sağlandığının bir göstergesidir denebilir.

\section{Kaynakça}

Barnard, M. (2002). Fashion and comunication. London and Newyork: Taylor\&Francis Group.

Barthes, R. (2012). Göstergebilimsel serüven. (S. Rifat ve M. Rifat, Eds. ve Çev.). İstanbul: Yapı Kredi Yayınları.

Batu, B. (2011). Sanat eğitimi alanında yapıt incelemelerinde bir yöntem olarak görsel gösterge çözümlemesi (Doktora Tezi). YÖK tez veri tabanından erişildi (Tez No. 285758).

Berger, J. (2008). Görme biçimleri. (Y. Salman, Ed. ve Çev.). İstanbul: Metin Yayınları.

Christian Dior. (2018, 4 Haziran). Erişim adresi: http://www.paragrafoku.com/2018/06/04/christian-dior/

Davis, F. (1997). Fashion, culture, and identity. (Ö. Arıkan, Ed. ve Çev.) İstanbul: Yapı Kredi Kültür Sanat.

Fiske, J. (2003). İletişim çalışmalarına giriş. (S. İrvan, Ed. ve Çev.), Ankara: Bilim Sanat.

Frog, M. (2014). Modanın tüm öyküsü. İstanbul: Hayalperest.

Girişmen, G. (2015). Moda tasarımında görsel kimlik ve imge algllanması (Yüksek Lisans Tezi). YÖK tez veri tabanından erişildi (Tez No. 421751).

Günay, V. (2008). Görsel okuryazarlık ve imgenin anlamlandırılması. Süleyman Demirel Üniversitesi Güzel Sanatlar Fakültesi Hakemli Dergisi (Art-e), 1(1), 1-29. Erişim adresi: https://dergipark.org.tr/tr/download/ article-file/193366

Kırkıncıoğlu, Z. (2015). Ege bölgesi kadın giyim-kuşamının göstergebilimsel yöntem ile çözümlenmesi (Doktora Tezi). YÖK tez veri tabanından erişildi (Tez No. 397379).

Koca, E., \& Kırkıncıŏ̆lu, Z. (2016). Denizli ili gelin giyim-kuşamının göstergebilimsel açıdan çözümlenmesi. Turkish Studies (International Periodical for the Languages, Literature and History of Turkish or Turkic), 11(8), 247- 270. doi: http://dx.doi.org/10.7827/TurkishStudies.9569

Koç, A. (2009). Kütahya merkezinde giyim-kuşam kültüründeki değişmelerin çözümlenmesi. Uluslararası Sosyal Araştırmalar Dergisi, 2(9), 243-261. Erişim adresi: http://www.sosyalarastirmalar.com/cilt2/sayi9pdf/koc adem.pdf

Koç, F., \& Koca, E. (2015). Kütahya'nın entarili geleneksel kadın giysilerinin göstergebilimsel çözümlenmesi. Milli Folklor, 27(106), 70-87. Erişim adresi: https://www.millifolklor.com/PdfViewer.aspx? Sayi $=106 \&$ Sayfa $=67$

Köse, H. (2007). Kültürel/siyasal bir kimlikleşme aracı olarak giyim-kuşam modası. ICANAS, 10, 457

Merriam, S. B. (2013). Nitel araştırma desen ve uygulama için bir rehber (S. Turan, Ed. ve Çev.) Ankara: Nobel Yayıncilık. 
Moda, modanın tarihçesi ve geçmişten günümüze ünlü modacılar. (2016,1 Nisan). Erişim adresi: https:/circlelove.co/moda-modanin-tarihcesi-ve-gecmisten-gunumuze-unlu-modacilar/

Özmutlu, A. (2009). Grafik tasarım atölye derslerine afiş konusunun uygulama ve çözümleme süreçlerinde göstergebilimsel çözümleme yönteminin kullanımı (Yüksek Lisans Tezi). YÖK tez veri tabanından erişildi (Tez No. 227527).

Parsa, S. (2004). Göstergebilim çözümlemeleri. İzmir: Ege Üniversitesi Basımevi.

Rifat, M. (1992). Göstergebilimin ABC'si. İstanbul: Simavi Yayınları.

Vardar, B. (2001). Dilbilimin temel kavram ve ilkeleri. İstanbul: Multilingual Yayınları.

Yıldız, Ş., \& Başak, V. (2019). Moda tarihi içerisinde Jan Van Eyck'in resimlerinin göstergebilimi ile analizi. International Journal of Interdisciplinary and Intercultural Art, 4(7), 179-200. doi: http://dx.doi.org/10. 29228/ijiia.7.81 